\title{
A tropomyosin-receptor kinase-fused gene mutation associates with vacuolar myopathy
}

Nicolas N. Madigan, MB BCh, PhD, Jennifer A. Tracy, MD, William J. Litchy, MD, Zhiyv Niu, PhD, Chunhua Chen, PhD, Kun Ling, PhD, and Margherita Milone, MD, PhD

Neurol Genet 2018;4:e287. doi:10.1212/NXG.0000000000000287

A 44-year-old Caucasian man presented with a 7-year history of upper and lower limb muscle fasciculations and cramps, progressive asymmetric weakness, muscle atrophy, and lengthdependent sensory loss. His parents (deceased), 3 older siblings, and 3 children had no history of neurologic symptoms, including weakness and sensory symptoms, with the exception of cramps in the mother. He was not taking any medication known to cause neuropathy or myopathy. On examination, there was right greater than left shoulder girdle muscle weakness and atrophy (Medical Research Council grades $3 / 5$ and 4/5), intrinsic left hand muscle weakness $(4+/ 5)$ with atrophy, asymmetric pelvic girdle $(4 / 5$ right, $3 / 5$ left), and left foot dorsiflexor weakness $(4+/ 5)$. Strength of neck flexor and extensors, and axial muscles, was normal. He had bilateral calf muscle atrophy and weakness as suggested by his inability to stand on toes (figure, A-C). He was areflexic. Sensory examination revealed distal vibration and pinprick deficits in the upper and lower limbs in a length-dependent fashion. He had bilateral pes cavus.

Serial measurements of serum creatine kinase ranged between 840 and 2,400 U/L (normal $<336 \mathrm{U} / \mathrm{L}$ ) over the preceding 4 years. MRI revealed thigh muscle atrophy (figure, D). Neurophysiologic studies demonstrated reduced motor conduction amplitudes and diffuse fibrillation and fasciculation potentials with large motor unit potentials suggestive of a motor neuronopathy. No small motor unit potentials were recorded. Sensory nerve action potentials were absent in the upper and lower limbs.

A muscle biopsy of the quadriceps, performed a year prior to presentation in our clinic, showed mixed neurogenic and myopathic changes with several fibers containing rimmed and nonrimmed vacuoles, and perivascular inflammation (figure, E-J). Targeted next generation exome sequencing (NGS) of 95 genes associated with hereditary neuropathy and motor neuron disease detected a known pathogenic heterozygous missense variant in exon 8 (c.854C $>\mathrm{T}$, p.Pro285Leu) of the tropomyosin-receptor kinase-fused gene (TFG), located within a carboxyterminal proline-glutamine (P/Q)-rich domain. NGS of 104 genes associated with myopathies (appendix e-1, links.lww.com/NXG/A118), including myopathies with rimmed vacuoles, revealed no pathogenic variants. Living relatives declined genetic testing.

\section{Discussion}

Our patient presented with a classic clinical phenotype and a known pathologic genotype caused by a heterozygous TFG mutation, along with novel histologic evidence of vacuolar myopathy. TFG mutations were first identified in Okinawa and Kansai prefecture patients with autosomal dominant hereditary motor and sensory neuropathy (HMSN-P) manifesting with proximal weakness and distal sensory loss. ${ }^{1}$ Two of these kindreds carried the same TFG mutation detected in our patient. Limited muscle pathologic findings showing neurogenic changes (fiber type

\author{
Correspondence \\ Dr. Milone \\ milone.margherita@mayo.edu
}



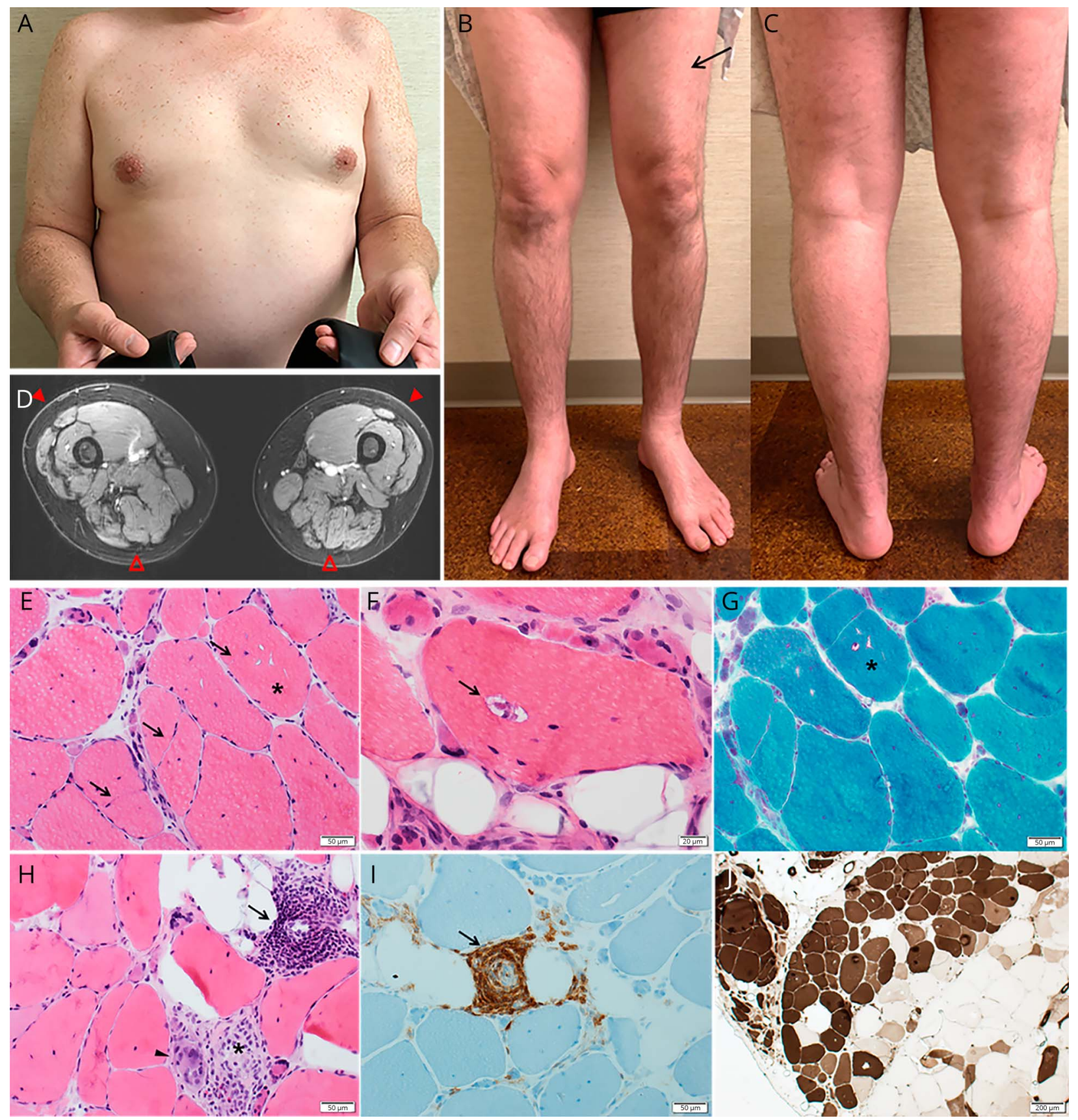

Patient photographs depicting pectoralis and biceps brachii atrophy (A), asymmetric quadriceps atrophy (B, arrow), anterior lower limb (B), and calf muscle atrophy (C). Muscle MRI (D) showing diffuse thigh muscle atrophy, greatest in the hamstring (open triangles) and vastus lateralis (solid triangles) muscles, bilaterally. Quadriceps muscle biopsy showing ( $E, F$, and $H$, hematoxylin-eosin) muscle fiber size variability ranging from 15 to $160 \mu m$, groups of atrophic fibers, fiber splitting and internalized nuclei (E, arrows), few fibers with multiple small non-rimmed vacuoles (E, asterisks, representative fiber), and increased perimysial fibrous and fatty connective tissue; rimmed vacuoles ( $F$, arrow, representative fiber), which were also observed in modified Gomori trichrome staining ( $G$, asterisk, fiber with rimmed vacuoles). Congo red-stained sections viewed under rhodamine optics revealed no congophilic deposits (data not shown). Regenerating $(\mathrm{H}$, arrow head) and necrotic $(\mathrm{H}$, asterisk) fibers and foci of perivascular inflammatory reactions $(\mathrm{H}$, arrow) were seen in some regions of the sections (hematoxylin-eosin). Immunocytochemical studies characterized the perivascular inflammatory cells as CD45 ${ }^{+}$(I); invasion of non-necrotic muscle fibers by inflammatory cells was not observed. ATPase reacted section ( $\mathrm{pH}$ 4.6) showed extensive grouping of the type 1 and type $2 \mathrm{~A}$ fibers in several fascicles ( ), where the darkest fibers are type 1 and lightest fibers are type $2 \mathrm{~A}$, suggestive of reinnervation; the atrophic fibers were of either histochemical type.

grouping) have been reported to date. Pathologic studies later demonstrated that HMSN-P is a motor neuronopathy with an associated sensory axonopathy. ${ }^{2}$ TFG-immunopositive inclusions in both sensory and motor neurons suggested pathologic similarities with other neurodegenerative diseases including amyotrophic lateral sclerosis (ALS). ${ }^{1,2}$ TFG-related neurologic disorders are now known to encompass a spectrum of phenotypes that includes autosomal dominant Charcot-Marie- 
Tooth disease type 2 (CMT2) and autosomal recessive hereditary spastic paraplegia. ${ }^{3}$

TFG protein is ubiquitously expressed in a variety of tissues, including normal muscle (data not shown). TFG functions primarily as a chaperone for vesicle trafficking of unfolded and misfolded proteins through the endoplasmic reticulum and into the ubiquitin-proteasome system (UPS). The P/Q domain in TFG specifically regulates the interaction with the UPS, and the TFG p.Pro285Leu variant has been shown to damage the protein quality control system. ${ }^{4}$ This could lead to accumulation of abnormal proteins in motor neurons as well as in muscle. Variants in heat shock proteins 22 (HSBP8) and 27 (HSPB1), which are also protein chaperones, have been associated with CMT2, motor neuronopathy, and vacuolar myopathy. Variants in valosin-containing protein (VCP), another protein involved in ubiquitin-dependent protein degradation, lead to a similar phenotypic spectrum. ${ }^{6}$

Low-complexity protein domains enriched for glutamine repeats, with proline $(\mathrm{P} / \mathrm{Q})$ and asparagine $(\mathrm{N} / \mathrm{Q})$, are also found in prions and are implicated in several degenerative neuromuscular disease models of DNA, RNA, and protein processing that result in cytoplasmic inclusions and templated protein propagation. ${ }^{7}$ The p.Glu384Lys mutation in TIA1 cytotoxic granule-associated RNA binding protein, for example, occurs directly within a glutamine-rich prion-related domain and causes distal myopathy with rimmed vacuoles, while an adjacent mutation (pPro362Leu) in the same low complexity domain has been reported in a kindred with ALS. Mutations in prion-like domains in hnRNPA2B1 and hnRNPA1 associate with vacuolar myopathy and motor neuron disease. Mutations in matrin-3, another RNA binding protein involved in stress granule formation, also lead to myopathy with rimmed vacuoles and ALS. TFG therefore extends the list of genes associating with vacuolar myopathy, motor neuron disease, and neuropathy.

\section{Acknowledgments}

The authors thank the patient for the photographs; Dr. A. Kendler at University of Cincinnati for sharing the muscle biopsy slides; and Invitae for performing the additional analysis of genes associated with myopathies.

\section{Study funding}

This work was supported by a generous gift from a Mayo Clinic benefactor to M. Milone and Z. Niu.

\section{Disclosure}

N.N. Madigan is an employee of the Mayo Clinic (neurology fellow). J.A. Tracy reports no disclosures. W.J. Litchy has received research funding from Ionis Pharmaceuticals and Alnylam (compensation for travel and training investigators). C. Chen reports no disclosures. K. Ling holds a patent for Phosphatidylinositol phosphate kinase type Igamma regulates focal adhesions and cell migration. M. Milone has received research funding from a Mayo Clinic benefactor, and through discretionary funding from the Department of Neurology. Full disclosure form information provided by the authors is available with the full text of this article at Neurology.org/NG.

Received July 3, 2018. Accepted in final form October 3, 2018.

\section{References}

1. Ishiura H, Sako W, Yoshida M, et al. The TRK-fused gene is mutated in hereditary motor and sensory neuropathy with proximal dominant involvement. Am J Hum Genet 2012;91:320-329.

2. Fujita K, Yoshida M, Sako W, et al. Brainstem and spinal cord motor neuron involvement with optineurin inclusions in proximal-dominant hereditary motor and sensory neuropathy. J Neurol Neurosurg Psychiatry 2011;82:1402-1403.

3. Tsai PC, Huang YH, Guo YC, et al. A novel TFG mutation causes Charcot-MarieTooth disease type 2 and impairs TFG function. Neurology 2014;83:903-912.

4. Yagi T, Ito D, Suzuki N. TFG-related neurologic disorders: new insights into relationships between endoplasmic reticulum and neurodegeneration. J Neuropathol Exp Neurol 2016;75:299-305.

5. Bugiardini E, Rossor AM, Lynch DS, et al. Homoygouse mutation in HSPB1 causing distal vacuolar myopathy and motor neuropathy. Neurol Genet 2017;3:e168.

6. Kazamel M, Sorenson EJ, McEvoy KM, et al. Clinical spectrum of valosin containing protein (VCP)-opathy. Muscle Nerve 2016;54:94-99.

7. An L, Harrison PM. The evolutionary scope and neurological disease linkage of yeastprion-like proteins in humans. Biol Direct 2016;11:32. 
Appendix 1 Author contributions

\begin{tabular}{|c|c|c|c|}
\hline Name & Location & Role & Contribution \\
\hline $\begin{array}{l}\text { Nicolas N. Madigan, } \\
\text { MB BCh, PhD }\end{array}$ & $\begin{array}{l}\text { Mayo Clinic, } \\
\text { Rochester, MN }\end{array}$ & Author & $\begin{array}{l}\text { Study concept and design; acquisition, analysis and interpretation of data; drafting manuscript; } \\
\text { critical revision of final manuscript for intellectual content. }\end{array}$ \\
\hline Jennifer A. Tracy, MD & $\begin{array}{l}\text { Mayo Clinic, } \\
\text { Rochester, MN }\end{array}$ & Author & $\begin{array}{l}\text { Acquisition, analysis, and interpretation of data; critical revision of final manuscript for } \\
\text { intellectual content. }\end{array}$ \\
\hline William J. Litchy, MD & $\begin{array}{l}\text { Mayo Clinic, } \\
\text { Rochester, MN }\end{array}$ & Author & $\begin{array}{l}\text { Acquisition, analysis, and interpretation of data; critical revision of final manuscript for } \\
\text { intellectual content. }\end{array}$ \\
\hline Zhiyv Niu, PhD & $\begin{array}{l}\text { Mayo Clinic, } \\
\text { Rochester, MN }\end{array}$ & Author & Analysis and interpretation of data; critical revision of final manuscript for intellectual content. \\
\hline Chunhua Chen, PhD & $\begin{array}{l}\text { Mayo Clinic, } \\
\text { Rochester, MN }\end{array}$ & Author & $\begin{array}{l}\text { Acquisition, analysis, and interpretation of data; critical revision of final manuscript for } \\
\text { intellectual content. }\end{array}$ \\
\hline Kun Ling, PhD & $\begin{array}{l}\text { Mayo Clinic, } \\
\text { Rochester, MN }\end{array}$ & Author & $\begin{array}{l}\text { Acquisition, analysis, and interpretation of data; critical revision of final manuscript for } \\
\text { intellectual content. }\end{array}$ \\
\hline $\begin{array}{l}\text { Margherita Milone, } \\
\text { MD, PhD }\end{array}$ & $\begin{array}{l}\text { Mayo Clinic, } \\
\text { Rochester, MN }\end{array}$ & Author & $\begin{array}{l}\text { Study concept and design; acquisition, analysis, and interpretation of data; drafting manuscript; } \\
\text { critical revision of final manuscript for intellectual content. }\end{array}$ \\
\hline
\end{tabular}




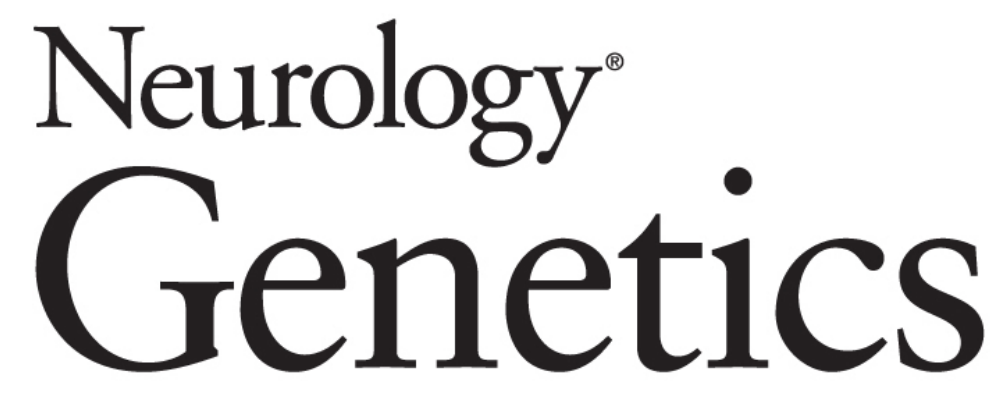

\section{A tropomyosin-receptor kinase-fused gene mutation associates with vacuolar myopathy Nicolas N. Madigan, Jennifer A. Tracy, William J. Litchy, et al. Neurol Genet 2018;4; \\ DOI 10.1212/NXG.0000000000000287}

This information is current as of November 7, 2018

\section{Updated Information \& Services}

References

Subspecialty Collections

Permissions \& Licensing

Reprints including high resolution figures, can be found at: http://ng.neurology.org/content/4/6/e287.full.html

This article cites 7 articles, 2 of which you can access for free at: http://ng.neurology.org/content/4/6/e287.full.html\#\#ref-list-1

This article, along with others on similar topics, appears in the following collection(s):

All Genetics

http://ng.neurology.org//cgi/collection/all_genetics

Anterior nerve cell disease

http://ng.neurology.org//cgi/collection/anterior_nerve_cell_disease

Muscle disease

http://ng.neurology.org//cgi/collection/muscle_disease

Peripheral neuropathy

http://ng.neurology.org//cgi/collection/peripheral_neuropathy

Information about reproducing this article in parts (figures,tables) or in its entirety can be found online at:

http://ng.neurology.org/misc/about.xhtml\#permissions

Information about ordering reprints can be found online: http://ng.neurology.org/misc/addir.xhtml\#reprintsus

Neurol Genet is an official journal of the American Academy of Neurology. Published since April 2015, it is an open-access, online-only, continuous publication journal. Copyright Copyright (C) 2018 The Author(s). Published by Wolters Kluwer Health, Inc. on behalf of the American Academy of Neurology.. All rights reserved. Online ISSN: 2376-7839.

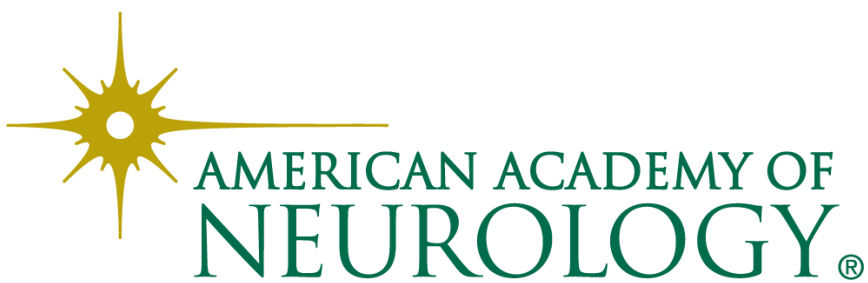

